\title{
The power of the future
}

\section{Jenny Andersson*}

(CNRS) MaxPo, SciencesPo, 28 rue des Saints Pères, 75006 Paris, France

*Correspondence: jenny.andersson@sciencespo.fr

Jens Beckert's Imagined futures is an impressive contribution to contemporary social theory. Following on his earlier investigations into processes of evaluation, Beckert proposes that capitalism is a set of future expectations. Dialoguing with an impressive range of authors from Durkheim to Bourdieu, Keynes and Morgenstern, Beckert boldly proposes that capitalism is organized prophecy, and that fields such as credit, innovation and consumption function through systematic speculation on the future. What Beckert refers to as fictional expectations make up a secular belief system in which market values of competitive behaviour and capitalist growth are totems.

A central ambition of Beckert's book is to link the macro and micro analyses of social processes by linking the assumptions of financial sociology with political economy. On the micro level, fictional expectations are a sociological challenge to the notion of rational expectations. In contrast to how economic theory assumes perfect information, Beckert suggests that actors cannot foreknow the future because no reliable knowledge exists concerning future developments. The future is therefore open, made up not of perfect information 
but of perfect uncertainty. Faced with this fundamental openness, actors need to create storylines and strategies that they can hold on to, and as economic actors cannot presume the rational behaviour of other economic actors, they set out to convince the set of intentions that make sense. They do so by mobilizing a set of narrative and calculative devices intended to transform Knightsean uncertainty into manageable risk. Beckert does not accept that there is any such thing as economic equilibrium. But where rational expectations theory presumes that economic actors anticipate future changes in such a way as to produce coordinated outcomes, Beckert also thinks that fictional expectations produce key forms of social coordination. If a set of fictional expectations is no longer credible, it will be replaced by something more credible, and in this manner, belief in the future is restored. Beliefs uphold, through this logic, a kind of functionality, which seems to presume that fictional narratives contribute to stable forms of social organization in which certain future patterns do become foreseeable and manageable.

On the macro level, Beckert proposes that fictionality is essentially religion and that it is the capacity of producing stories about the future that distinguishes capitalism from other socioeconomic systems. The idea that the future is open is the underpinning ideology of capitalism, because only if it is open can the future be filled with a set of expectations. This is not a new argument. Rather, Beckert is continuing a line of thought which was fundamental to German social theory and in particular the Bielefeld school with authors such as Reinhart Koselleck, Niklas Luhmann and Norbert Elias, and which linked modern capitalist societies with a particular idea of the future. ${ }^{1}$ The secular and bourgeois future, as argued for instance by Koselleck, was open, because it was freed from religious authority and could therefore be filled with forms of human action. A more recent wave of social thinking about the future has reversed this argument by posing the question of what the link between capitalism and the future did to the future as such. Claus Offe has proposed that capitalism and neoliberalism destroy social time by shrinking horizons of social action, and Adam and Groves (2005) has produced a set of deeply concerned writings about the way that modern capitalist societies operate with systemic time conflicts produced by the incompatibility of capitalist futures with futures of nature, or of human relations. Beckert is less interested in this line of thought, which arguably marks a different but also crucial legacy around the future in social theory. He mentions, for instance, Kenneth Boulding work on the image of the future (Beckert, 2016, p. 71) but does not give weight to the way Boulding's argument formed in fact a crucial objection to the system theory of Talcott Parsons by replacing functionality with human intention and love (Boulding, 1961).

Imagined futures explains how credit markets, innovation and consumption set out future promises, and how such promises are upheld by narratives that legitimize and stabilize these expectations. This stabilization of expectations, in financialized societies, is a big deal. It requires constant attempts not only by market actors but also by public authorities to actively manage expectations by setting out comforting and reassuring rhetorical messages (Holmes, 2014) some of which perform the modern function of oracle. A chapter devoted to modern forms of prediction in the form of economic forecasting indeed describes forecasting as prophecy. As prophecy, forecasting plays a most ambiguous role as allowing

1 Utopieforschung : interdisziplinare studien zur neuzeitlichen Utopie, see Norbert Elias, L'utopie, Edition la Decouverte, Paris, 2015, Reinhart Koselleck, Futures Past (Vergangene Zukunfts) MIT Press, 1985. 
both for a Schumpeterian process of creative destruction in a field like technological innovation (in other words the opening of new futures), and for calming Keynesian animal spirits by reassuring actors that in fact the future is foreseeable (hence not much different than the present). Forecasts are like other fictions only good for as long as we believe them, and the activity of forecasting is therefore surrounded by attempts to mobilize social legitimacy and credibility, including through the involvement of a multitude of professional and lay expertise (see Jasanoff and Kim, 2016).

This is perhaps the weakest argument of the book, and does not to a very large extent take into account the role played by forecasts and prophecies in upholding contemporary forms of social power. The growing literature on forecasting ascribes is a more ominous performatory function, indeed a range of authors see forecasts and scenarios as technologies with which market societies close down social futures (see Aradau and Munster, 2011; Anderson, 2010). Koselleck, in the first English translation of his forthcoming book Zeitschichten in an article in Economy and Society in 1982, argued that forecasting was a secular activity performed by the absolutist state to close again a future opened wide by the breakdown of religious authority. To Koselleck, forecast was thus a governmental mechanism for imposing authority on a dangerously open process of social and economic change (Koselleck, 1981). This is also how forms of prediction, in particular in insurance and more recently in disaster management for instance, has been understood by a range of essentially Foucauldian scholars (Ewald, 1991; Lakoff and Mallard, 2012). But Beckert's interest is not to understand the way that stabilizing the future might play a key role in an emerging new version of state capitalism, rather he understands the stabilization of expectations as part and parcel of financialized societies in which the stakes posed by uncertainty are so high that outbursts of animal spirits can simply not be allowed. The main result of governing expectations in Beckert's account is to contribute to forms of capitalist stability and dynamics, and its possible destabilizing effects are downplayed.

Meanwhile financial crisis has shown us that forecasting stable futures can have disastrous effects, and that predicting the future can be directly involved in large-scale processes of social destruction. Imagines futures does not, paradoxically, attribute much importance to the role played by forms of prediction in the run-up to the financial crisis. Forecasts that systematically downplayed financial risk were, as Donald McKenzie and others have shown, vehicles that allowed for distorted and false expectations on risk to continue to exist, magnify and create essentially a whole system of false beliefs about future performance (MacKenzie, 2008). They did not do so on their own, but as a result of careful architecture. If expectations are only good for as long as we believe in them, what are we to do with situations in which actors go to great length to produce forms of legitimacy and credibility around future visions that turn out to be either wishful thinking or smoke screens for less visible and more disturbing things? Or with situations in which, as Oreskes' study of tobacco companies shows, actors coldheartedly produce ignorance and invent ways of actively unknowing the future (Oreskes and Conway, 2010)? Arguably, both the financial crisis and climate change confront us with a problematic future made up by the futuristic behaviour of capitalism. In this situation, the future is not open but acted on (futures are, in the end, the results of our actions, including or non-action). This is a situation in which things can and are certainly known about the future, but in which there are also fundamental asymmetries in the social actors who control what we know and are to know about futures. In such situations, forecasts are not, I would propose, stories of what if, as Beckert 
proposes. They are rather oftentimes highly imperative will be, highly authoritative accounts of the necessity of a particular social development. While they may be fictitious in drawing on narration and storytelling, they tend to be backed up by resourceful interests. In the wide array of possible futures that present themselves to us if the future were indeed open, some mechanism accounts for the realization of a particular future. Indeed why do we live with capitalism? While the importance given by Beckert to fiction, narrative and image in the social process of creating future is an important step forward from other deterministic accounts of the future, we should pay much more attention to how fictionality is backed up by a material game of future interest, and how the future itself is produced and by whom.

\section{References}

Adam, B. and Groves, C. (2005) Future matters. Amsterdam, Brill.

Aradau, C. and Van Munster, R. (2011) Politics of catastrophe: Genealogies of the unknown. London, Routledge.

Boulding, K. (1961) The Image. Knowledge in Life and Society, Ann Arbor, University of Michigan Press.

Ewald, F. (1991) 'Insurance and Risk'. In Burchell, G. et al. The Foucault effect, Studies in Governmentality, Chicago, University of Chicago Press.

Holmes D. (2014) Economy of Words. Communicative Imperatives in Central Banks, Chicago, University of Chicago Press.

Jasanoff, S. and Kim, S.-Y. (2016) Dreamscapes of Modernity. Sociotechnical Imaginaries and the Fabrication of Power, Cambridge, MA, Harvard University Press.

Koselleck, R. (1981) 'Modernity and the Planes of Historicity', Economy and Society, 10, 166-183.

Lakoff, A. and Mallard, G. (2012) 'How Claims to Know the Future are Used to Understand the Present'. In Lamont, M. et al. (eds) Social Knowledge in the Making, Chicago, University of Chicago Press.

MacKenzie, D. (2008) An Engine, Not a Camera. How Financial Models Shape Markets, Cambridge, MA, MIT Press.

Oreskes, N. and Conway, E. M. (2010) Merchants of Doubt, New York, Bloomsbury. 